\title{
STATE COMPETITION POLICY: CONCEPT, LEGAL REGULATION AND MECHANISMS OF ITS IMPLEMENTATION
}

\author{
Andrii Manzhula ${ }^{1}$ \\ Volodymyr Vynnychenko Central Ukrainian State Pedagogical University, Ukraine \\ Dmyto Pryputen², Liliia Mezhevska ${ }^{3}$ \\ Dnipropetrovsk State University of Internal Affairs, Ukraine
}

\begin{abstract}
The purpose of the paper is to analyze the definition "state competition policy", its essence, functions and mechanisms of implementation. The main purpose of competition policy is to ensure and promote the development of competition in the country, minimize market monopolization and ensure the functioning of a market economy through fair competitive methods. All these goals can be achieved only through the use of effective mechanisms and tools for the implementation of competition policy by the state authority. Methodology. Competition policy of the state, as one of the directions of economic policy, requires revision of the means and mechanisms for its implementation for an effective functioning of the market. There is a need to reconsider the powers of competition authorities and the urgency of application of legislative and regulatory acts providing these issues, for an effective implementation of the competition policy and achievement of the goals. Results. Despite a considerable amount of various definitions of the concept of state competition policy, its main objectives are to promote competition at the marketplaces, and the promotion and protection of competition. Practical implications. The government's competition policy is an instrument, the effectiveness of which proportionately depends on the functions performed by the state aimed at the achievement of positive results, specifically related to the support of competitive environment in the process of economic activity, support of competition in certain sectors of the economy, prevention of anti-competitive practices etc. Value/originality. A significant role in this context is played by introduction of amendments to national competition law and harmonization of this legislation with competition law of member states of the EU. It is necessary to reconsider the competences and powers of competition authorities, their operational efficiency and interaction of bodies with national and international organizations regulating competition protection issues.
\end{abstract}

Key words: state competition policy, means of implementation of competition policy, mechanisms of implementation of competition policy, state policy, functions of competition policy.

JEL Classification: E44, H1, K1, K13

\section{Introduction}

The effectiveness of a competition policy of the state and the use of viable mechanisms for its implementation is a guarantee of a proper functioning of the market and the growth of the competitiveness of goods and services. The mechanisms of regulation of competition play an important role in guarantee of a competitive environment. In particular, this issue becomes extremely relevant in the context of globalization and openness of the market.

Many researchers of economy and law who deal with this concept in various broad and narrow terms are engaged in research in this area, emphasizing the main characteristics, directions, goals and mechanisms of the use of methods of competitive struggle. The author analyzed many articles devoted to the mechanisms of the implementation of competition policy, in particular the researches of V. Lahutin "Competition policy of the state: mechanisms of implementation” (Lahutin, 2016), which considers all mechanisms from the perspective of economy, also, the works of $\mathrm{H}$. Filyuk were analyzed, in particular, the article "Competition policy of the state in the conditions of globalization" (Fyliuk, 2009)

\footnotetext{
Corresponding author:

${ }^{1}$ Department of Branch Law and Law Enforcement Activities, Volodymyr Vynnychenko Central Ukrainian State Pedagogical University.

E-mail: mors200708@ukr.net

${ }^{2}$ Department of General Law Disciplines, Dnipropetrovsk State University of Internal Affairs.

E-mail: dm 86@mail.ua

${ }^{3}$ Faculty of Law, Dnipropetrovsk State University of Internal Affairs.

E-mail: megevska38@gmail.com
} 
as well as the article of P. Lazur "Peculiarities of the policy of formation of a competitive environment in entrepreneurial activity" (Lazur, 2007), etc. However, the author emphasizes the need to consider the problem from a legal point of view. Based on the proposed definitions and a detailed analysis of the definitions, the author gives his own concept of competition policy through the prism of functional purpose, emphasizing the need to consolidate the mechanisms of regulation and application of effective methods of competition promotion, prevention of anti-competitive offenses and application of responsibility which is commensurable with the damage caused by such offenses. All these activities should take place at the legislative level and have action-oriented character of application.

The article is devoted to the solution of the main tasks as follows:

1. To study the opinions of scholars relatively the definition of state competition policy.

2. To make a detailed analysis of the Ukrainian legislation concerning competition regulation, consolidated in European normative legal acts.

3. To consider competition policy of the state through the prism of its functional purpose, which includes in its genesis both static and dynamic directions.

4. To propose effective directions for improvement of the implementation of state competition policy, which should be consolidated at the legislative level.

\section{Competition as the basis of a market system}

Competition as the basis of the entire market system is an incentive to ensure a vital functioning of the market. A competitive environment in the state can be achieved only due to well-developed state competition policy, which in turn requires a thoroughly elaborated strategy and tactics. The main goal and direction of the state's economic policy is realization and optimal congruence of interests of business entities and consumers, based on a mixture of private and public interests through methods of competition promotion. The Commercial Code defines antitrust-competition policy as one of the main directions of the economic policy of the state, the main focus of which is to create an optimal competitive environment for the activity of business entities, maintenance of their interaction under conditions of prevention of discriminatory practices of some entities towards others (Hospodarskyi kodeks Ukrainy), that is, based on the principle of equality and nondiscrimination, and access to markets for all entities on equal terms. The main objective of competition policy, along with the combination of private and public interests, is the growth of an effective socially oriented market economy based on overcoming monopoly.

The real state of competition in the market and free goods turnover, free access to the market of consumers and business entities is possible only by virtue of well-developed mechanisms for the implementation of competition policy, which in turn is achieved by a combination of administrative regulation and the consolidation of effective competitive norms at the legislative level. Competition authorities, along with preventive methods, should apply mechanisms for stimulation and development of competition, protection of business entities from manifestation of unfair competition. Unfortunately, the realities of the present are such that unfair competition methods largely dominate honest and fair rules of competition, consequently causing a disorder of market functioning.

As it follows from the norms of legislation, the main task of the Antimonopoly Committee of Ukraine is to participate in the formation and implementation of competition policy. The Law of Ukraine "On Antimonopoly Committee" (Pro Antymonopolnyi komitet Ukrainy) clears up in detail the tasks, powers and competencies of AMCU in relation to the implementation of antimonopoly policy of the state. But there is an issue of reconsideration of the mechanisms of practical application of set goals and tasks and introduction of cooperation with executive bodies of state and regional importance. At the same time, V.Mahas notes that it is necessary to understand that AMCU is unable to solve the issue of market demonopolization independently without implementing a systemic economic policy aimed at removal of the reasons which favour monopolization (Mahas, 2017).

The growth of competitiveness of the national economy and competitiveness of its own products at the national level, free market access as for consumers as economy entities, reduction of barriers of market entry and exit can be achieved only through reconsideration of legislative provisions and introduction of effective mechanisms in practice.

Today, we have a situation where the norms consolidated in the current laws do not have effective application, all while generating certain negative consequences of the market activity. On this issue, the author emphasizes the need of reconsideration of legislation in effect and implementation of efficient norms, the primary tasks of which will be to develop both policy documents and strategies for the development of competition in the market. An important point is to overcome monopolized markets in many sectors, to ensure equal opportunities for market entry of all business entities and to remove barriers for market entry, including administrative ones.

\section{Definition of the concepts "antitrust policy", "antimonopoly policy", "competition policy", "antimonopoly-competition policy"}

Along with the notion "competition policy", in modern economic science there are the concepts "antitrust policy", "antimonopoly policy", "antimonopolycompetition", etc. 
The main focus of antitrust and antimonopoly policy is a strict prohibition of the existence of monopolies and trusts, any kind of conspiracies for which even criminal liability is foreseen. The European model, a more specific name for which is competition policy, allows one to occupy a monopoly (dominant) position on the market, while prohibiting abuse of this dominant position and market power. The Ukrainian model is more prone to the European model of competition regulation, while Ukrainian legislation does not have a clear definition of this policy. The Commercial Code is called "antimonopoly-competition policy" (Hospodarskyi kodeks Ukrainy), while the Law of Ukraine "On Protection of Economic Competition" defines it as a policy in the field of development of economic competition and restriction of monopoly in economic activity (Pro zakhyst ekonomichnoi konkurentsii). Today, most scholars insist on the need to balance competition policy with industrial, innovation, investment, pricing and other policies defined in the economic code (Lazur, 2007).

Such international organizations as the WTO, the World Bank, UNCTAD, WIPO, OECD, ICAP pay attention to the definition of the concept "competition policy". Their cooperation with competent authorities of different countries aimed at harmonization of national competition policies and mechanisms of its implementation (Lazur, 2007).

Analyzed the definition of scientists in relation to the competition policy of the state, in particular, proposed by such scholars as Z. Borysenko, V. Lahutin, H. Fyliuk, P. Lazur, etc., and the definitions given by the World Trade Organization and the World Bank, the author highlights the main trends of competition policy aimed at prevention and cessation of violations of antimonopoly regulation, with that the main focus is creation of the competition environment. This issue can be realized only through the use of effective methods of influence, the use of the responsibility for these violations by the antimonopoly authorities, along with the introduction of incentive methods for the development of competition. An important aspect is the instrumental nature of competition policy as the desired result will be achieved only due to the use of effective tools.

\section{Functional use of competition policy, mechanisms of its implementation}

Examining the essence of competition policy, it is important to understand its functional purpose. Let's consider it through the prism of the functions of economic competition, among which are regulatory, stimulating and control-signaling. By the same classification, it is possible to divide the functions of competition policy that have both static and dynamic directions in its genesis. The regulatory function has features of static character and consists in the establishment of rules of competitive practices, which is provided by regulation on the part of anti-monopoly authorities, in order to prevent the concentration of power in one's hands, regulation and support of the level of competition in the country and prevention of abuses by monopoly entities. The stimulating function should be aimed at motivation of competition participants to improve production, introduce innovations, improve the quality of products, enter the international markets and increase the competitiveness of the national economy. This function has more dynamic aspect in the context of creation of the necessary conditions for the development of competitive national commodity producers that could be worthy competitors in the world markets. Along with it, it is impossible to skip the consideration of the control-signaling function, which is a kind of driver of economic development and lies in monitoring of participants of competition over their own production in terms of its efficiency, which due to certain signals on the market in relation to the supply and demand for one or other goods, the possibility of entrance to the new markets or entrance to the markets of potential competitors, induces the business entities to improve their own production. An active policy of the state should be oriented to the interaction of competition policy with industrial, innovative, investment and other areas of economic policy of the state, the main task of which should be to ensure the competitiveness of enterprises both in the domestic and foreign markets as well as the competitiveness of the national economy as a whole.

It is impossible to consider competition policy separately from other directions of the economic policy of the state. The main goal should be functioning of the market on the basis of balancing public and private interests, while it is necessary to balance the interests of private entrepreneurs in the normal functioning of their business in the home country and in international markets as well as the state's interest in maintaining the level of competitiveness of national goods and commodity producers in the world arena.

The necessary and important task of realization of the competition policy is overcoming the existing level of monopolized markets, creation of a decent competitive environment, and not only consolidation of this concept at the legislative level. All this requires the use of effective methods of government and a revision of legislative provision on this issue. The norms of national competition law need revising and improving based on the experience of foreign countries.

Increase of the effectiveness of antimonopoly and competitive regulation can be achieved only through the establishment and implementation of the State Concept and the State program of measures of guarantee and support of competitive principles for the functioning of the national economy and assistance of 
its long-term competitiveness and will be developed taking into account international standards in this area and agreed with the relevant EU documents. Such approach will allow Ukraine to continue harmonization of domestic competition law with best international practices and to take into account the conditions for the implementation of competition policy in the context of globalization. The main goals of this concept should be to achieve a reduction of the level of the shadow economy and corruption; reduction of barriers for enter of new business entities to the market, reduction and rationalization of state interference and improvement of control over subjects of natural monopolies, which requires the creation of controlling bodies in those spheres of natural monopolies where they have not yet been created; clear distribution of functions between different controlling structures; bringing the domestic legislative framework in line with international law, etc.

It also needs to revise and reconsider the provisions of the Law of Ukraine "On the Development and State Support of Small and Medium Business" (Pro rozvytok ta derzhavnu pidtrymku maloho i serednoho pidpryiemnytstva $\mathrm{v}$ Ukraini) in terms of tax legislation and the provision of privileges to small businesses at the development stage. It's hard for a small business to compete with large giant companies creating artificial barriers for entry.

According D. V. Zadykhailo, Ukraine's accession to the $\mathrm{WTO}$ also requires providing the national producers with the highest possible level of competitiveness with the help of active means of state regulation. The problem of guarantee of economic growth due to innovative factors of production with all the very favourable social and environmental consequences of such structural transformations is also impossible without an active state economic policy, appropriate state regulation of economic relations (Zadykhailo, 2012).

Anti-competitive concerted actions, which may even have a global scale, are a real disaster for the economy and for competitive situation in the market. In foreign laws, we find the concept of cartels or cartel conspiracies, which is one of the most dangerous violations of antitrust laws. The European Union legislation prohibits the existence of concerted behavior between economic agents which may adversely affect trade between member countries, impede competition within the common market, restrict or distort it as referred to in Article 101 of the Treaty on the Functioning of the European Union (Pro rozvytok ta derzhavnu pidtrymku maloho i serednoho pidpryiemnytstva v Ukraini). In Ukraine, the level of anticompetitive conspiracies is quite large, in particular as at the horizontal as at the vertical levels. Along with the arrangements that have any written evidence of the existence of a connection between the cartel participants, a situation is often formed where is very difficult to find out the existence of a conspiracy, so-called "gentleman's agreements", which have enormous complexity in relation to the evidence base and the possibility to bring offenders to responsibility. Cartels have features of stability while each enterprise keeps its autonomy of functioning. The Law of Ukraine "On Protection of Economic Competition" (Pro zakhyst ekonomichnoi konkurentsii) highlights the distortion of bidding results, tenders, auctions, which is a conspiracy between a party and a customer in the field of public procurement, as one of the most popular and widespread forms of anticompetitive concerted actions. Even after the introduction into effect of the system of electronic procurement, this type of offenses continues to be the most widespread, and therefore the system of conduction of electronic trade and the Law of Ukraine "On Public Procurement" (Pro publichni zakupivli) also needs to be improved.

The Ukrainian legislation highlights a number of violations in the field of protection of economic competition and protection against unfair competition along with the abuse of a monopoly position and anticompetitive concerted actions that lead to violation, restriction or elimination of competition. Above mentioned offences have negative consequences for the Ukrainian economy, and therefore the author stresses the need to reconsider the rules that regulate the issues and modernize the methods of struggle against the manifestations of antitrust violations and the application of appropriate sanctions.

An own base of legal regulation of competitive relations is developed at the level of international regulatory legal acts. It is important to understand that national competition law must be harmonized in some way with European law, but taking into account the peculiarities of national application of legislative norms, there should be its own categorical apparatus, its own means and tools for the implementation of competition policy, and a balanced system of mutual relations. Harmonization and, in some cases, unification of competition law at the supranational level takes place, mainly within the framework of intergovernmental organizations. The most famous and most successful example is the European Union, which created a single competition law for all member states.

\section{Conclusion}

According to the results of the study of the application of effective mechanisms for implementation of a competitive policy for the adequate functioning of a market economy, we can come to the following conclusions.

1. State competition policy has an instrumental nature and its effectiveness proportionally depends on to the performed functions aimed at the achievement of practical results - maintaining the competitive conditions in economic activities, maintaining the state of competition in certain sectors of the economy, prevention of anti-competitive practices, etc. 
2. The legal aspect of consolidation of competition policy at the legislative level needs a thoroughly reconsideration and improvement, the main areas of which should be optimization oflegal means of guarantee of competition's decent level, the systematization of competition law and the legal provision of the necessary competencies of the Antimonopoly Committee of Ukraine. Improvement of the national competition law and its harmonization with the competition law of the EU countries plays an important role in this sense.

3. The main directions of state competition policy are maintaining the level of competition in the country, which can be achieved only through the application of effective mechanisms of implementation of the policy by the anti-monopoly authorities.
4. The main directions of competition policy should be the overcoming monopoly entities; creation of a real level of competition and reduction of barriers mark entry and exit of new business entities; overcoming the level of corruptions of state bodies; application of more effective mechanisms of combating unfair competition; regulation of the issue of activity of natural monopoly entities and creation of more effective regulators in these spheres; creation of economic conditions for guarantee of international economic competitiveness of national economic entities, etc. These measures can be realized through the proper use of the tools and be clearly differentiated depending on the types of goods, works or services as well as depending on the supply and sale markets.

\section{References:}

Borysenko Z. (2004) Osnovy konkurentnoi polityky: pidruchnyk [Basis of competition policy]. Kyiv: Takson. (in Ukrainian)

Lahutin V. (2016) Konkurentna polityka derzhavy: mekhanizmy realizatsii [Competitive policy of the state: mechanisms of implementation]. Visnyk KNTEU no. 4, pp. 22-37.

Fyliuk H. (2009) Konkurentna polityka derzhavy v umovakh hlobalizatsii [Competition policy of the state in the context of globalization]. Visnyk Kyivskoho natsionalnoho universytetu im. T. Shevchenka, no. 109, pp. 46-53.

Mahas V. (2017) Konkurentsiia - holovna meta ekonomichnoi polityky. [Competition is the main objective of economic policy. Proceedings of the Stratehiia realizatsii konkurentnoipolityky Ukrainy vkontekstiyevrointehratsiinykh vyklykiv: materialy Mizhnarodnoi naukovo-praktychnoi konferentsii (Kyiv, April 27, 2017), Kyiv: KNUBA, pp. 57-60.

Lazur P. (2007) Osoblyvosti polityky formuvannia konkurentnoho seredovyshcha u pidpryiemnytskii diialnosti [Peculiarities of the policy of development of competitive environment]. Retrieved from: http://www.rusnauka.com/2. SND_2007/Economics/19232.doc.htm (accessed 15 December 2017).

The Verkhovna Rada of Ukraine (2003) Hospodarskyi kodeks Ukrainy: Zakon Ukrainy vid 16.01.2003 r. № 436 IV [The Commercial Code of Ukraine: the Law of Ukraine dated 16.01.2003 No 436-IV. Vidomosti Verkhovnoi Rady Ukrainy, no. 18-22, Art. 144.

The Verkovna Rada of Ukraine (2016) Pro Antymonopolnyi komitet Ukrainy: Zakon Ukrainy vid 26.11.1993 r. № 3659-XII [On the Antimonopoly Committee of Ukraine: the Law of Ukraine dated 26.11.1993 No 3659-XII]. Vidomosti Verkhovnoi Rady Ukrainy, no. 50, Art. 472.

The Verkovna Rada of Ukraine (2016) Pro publichni zakupivli : Zakon Ukrainy vid 25.12.2015 r. № 922-VIII [On Public Procurement: the Law of U+kraine dated 25.12.2015 No 922-VIII]. Vidomosti Verkhovnoi Rady Ukrainy, no. 9, Art. 89.

The Verkovna Rada of Ukraine (2001), Pro zakhyst ekonomichnoi konkurentsii: Zakon Ukrainy vid 11.01.2001 r. № 2210-III [On Protection of Economic Competition: the Law of Ukraine dated 11.01.2001 No 2210-III]. Vidomosti Verkhovnoi Rady Ukrainy, no. 12, Art. 64.

WTO (1999) “The Fundamental Principles of Competition Policy: Background Note by the Secretariat”. Working Group on the Interaction between Trade and Competition Policy WT/WGTCP/W/127, June 1999, para 4.

Khemani, R. Shyam (1998) A Framework for the Design and Implementation of Competition Law and Policy. Washington: World Bank. Retrieved from: http://www.oecd.org/regreform/sectors/ aframeworkforthedesignandimplementationofcompetitionlawandpolicy.htm (accessed: 15 December 2017).

Zadykhailo D. V. (2012) Hospodarsko-pravove zabezpechennia ekonomichnoi polityky derzhavy: monohrafiia [Economic and legal support of the state economic policy: monograph], Kharkiv: Yurait, pp. 456.

Official Journal of the European Union (2012). Consolidated version of the Treaty on European Union and the Treaty on the Functioning of the European Union, Official Journal of the European Union, pp. 323, 1-390. Retrieved from: http://eur-lex.europa.eu/legal-content/EN/TXT/?uri=celex\%3A12012E\%2FTXT

The Verkhovna Rada (2013) Pro rozvytok ta derzhavnu pidtrymku maloho i serednoho pidpryiemnytstva v Ukraini: Zakon Ukrainy vid 22.03.2012 r. № 4618- VI [On the Development and State Support of Small and Medium Business in Ukraine: the Law of Ukraine dated 22.03.2012 No 4618-VI]. Vidomosti Verkhovnoi Rady Ukrainy, no. 3, Art. 23. 